\title{
Factors Affecting the Integration of Auditory and Visual Information in speech
}

\author{
OMasahiro HASHIMOTO (UOEH, Human Information Lab.) \\ Masaharu KUMASHIRO (UOEH, Dept.of Ergonomics)
}

\section{1 はじめに}

音声知覚における視覚情報と聴覚情報の統 合過程を示すひとつの現象として、McGurk 効果がある。仮に、映像が/ga/ で音声が/ba/ であるような矛盾したビデオ刺激を呈示する

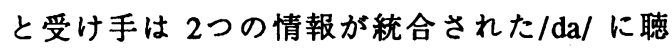
取する ${ }^{1)}$ 。但し、McGurkらの実験では、映 像と音声が同期していた。一方、映像と音声 が同期していないとき McGurk効果が認めら れるかどうかについては十分に検討されてい ない。本稿の目的は、音声の視覚情報と聴覚 情報が統合される時間的な限界を明かにする ことである。それ故、実験では相矛盾する 映像と音声を時間的にずらして呈示したとき、 梘聴覚情報の統合現象、すなわち McGurk 効 果にどのような変化が認められるかについて 検討した。

\section{2 方 法}

\section{1. 刺激}

日本人女性の発話した日本語単音節/ba/ $/ \mathrm{pa} / 、 / \mathrm{ma} / 、 / \mathrm{wa} / 、 / \mathrm{ga} /, / \mathrm{da} / 、 / \mathrm{ta} /, / \mathrm{ka} /$ 、 $/ \mathrm{na} /$ 、/ $\mathrm{ra} /$ の計10音節の映像と音声を視聴覚 刺激として用いた。刺激の組み合わせ方は、 唇音の4音 $\times$ 非唇音の6映像、非唇音の6音 $\times$ 唇音の4映像、および映像と音声が一致する 10 刺激の計 58 通り。音声と映像の呈示時間 の関係は、音声が映像に先行する場合をマイ ナス、音声が映像より遅延する場合をブラス で表示すると $\pm 50 、 \pm 100 、 \pm 150 、 \pm 200 、$ $\pm 400 \mathrm{msec}$ の 10 通り。比較のために、音声と 映像が同期した刺激系列と音声のみの刺激系
列も作成した。刺激作成の詳細な手続きは文 献(2)に記載されている。

\section{2. 手続き}

各呈示タイミング別に58通りの刺激を7秒 間隔で無作為にタビング編集したVHSテーブ の刺激系列をビデオ再生した。梘覚刺激（映 像）は21インチのカラーモニターより視距離 $1 \mathrm{~m}$ で聴覚刺激 (音声) はモニタ一両側面 のスピーカより呈示した。聴覚刺激の呈示レ ベルは被験者頭上約60、70、80dBSPLの3 条件とし、各条件に6人ずっの被験者（合計 18人）を割り当てた。いずれの被験者も視力、 聴力とも正常な成人女性であった。被験者に は映像と音声の双方に注意を向けて、"見た ことではなく、聞いたことを書く"ように教 示した。なお、視覚刺激と聴覚刺激が矛盾し ていることは知らせなかった。

\section{3 結果および考察}

視覚刺激と聴覚刺激の組み合わせ方の違い とMcGurk効果の生起率との関係を3つの呈示 レベルについて示したのが図1である。

1）刺激の組み合わせ方の違いによって、 McGurk 効果の生起率は全く異なっていた。 非唇音の視覚刺激と唇音の聴覚刺激を組み合 わせた場合、いずれの呈示レベルにおいても

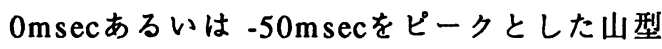
の生起率曲線を示した。一方、その逆の組み 合わせでは、 $80 \mathrm{~dB} の 0 \mathrm{msec}$ 条件を除いて McGurk効果はほとんど観察されなかった。 2）刺激の呈示レベルによってMcGurk 効果 の生起率曲線は異なる傾向を示していた。 
映像に対して音声が先行した場合、いずれの 呈示レベルにおいても2つの刺激の時間的な ずれが大きくなるにつれMcGurk 効果は減少 した。しかしながら、呈示レベル $60 \mathrm{~dB}, 70 \mathrm{~dB}$ と、80dBでは生起率の減少パターンが明かに 異なっていた（p<0.05）。McGurk 効果が消 失する音声の先行時間は、 $60 \mathrm{~dB}$ 呈示で $400 \mathrm{msec} 、 70 \mathrm{~dB} て 2200 \mathrm{msec} 、 80 \mathrm{~dB}$ で $150 \mathrm{~m} \mathrm{sec}$ であった。一方、映像に対して音声が遅延し たときMcGurk 効果が消失する遅延時間は、 $60 \mathrm{~dB}$ 呈示で $400 \mathrm{msec} 、 70 \mathrm{~dB}$ と $80 \mathrm{~dB}$ 呈示では $200 \mathrm{msec}$ あった。さらに、これらの呈示条 件では、音声が $100 \%$ 聴取されていた。した がって、McGurk 効果の消失は被験者によっ て視覚情報と聴覚情報が別々の情報として処 理されたものと推測される。

\section{4 まとめ}

本稿では、McGurk効果に時間的な限界か あること、音声の視覚情報と聴覚情報が統合 されるためには、2つの情報が時間的にある 程度一致していることが必要であることが示 された。すなわち、音声知覚において時間的 に一致した視聴覚情報が統合されるのであり、

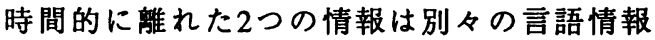
として処理されることが示唆された。さらに、 時間的に離れた2つの情報を同じ音声情報の 一部として受け入れる基準は、音声の呈示レ ベルによって異なることも示唆された。

謝 辞 実験刺激は、千葉工業大学情報工学科 世木 秀明先生の指導により千葉工業大学大学院修士課程在 学中に坂口裕昭氏が作成したものである。ここに記し て感謝申し上げます。

\section{参考文献}

1) McGurk, H. and MacDonald,J. Nature, 264, 746-748, 1976.

2) 坂口、世木、出口. 音䔩学会講演論文集， 1-7-4, 1993-3.
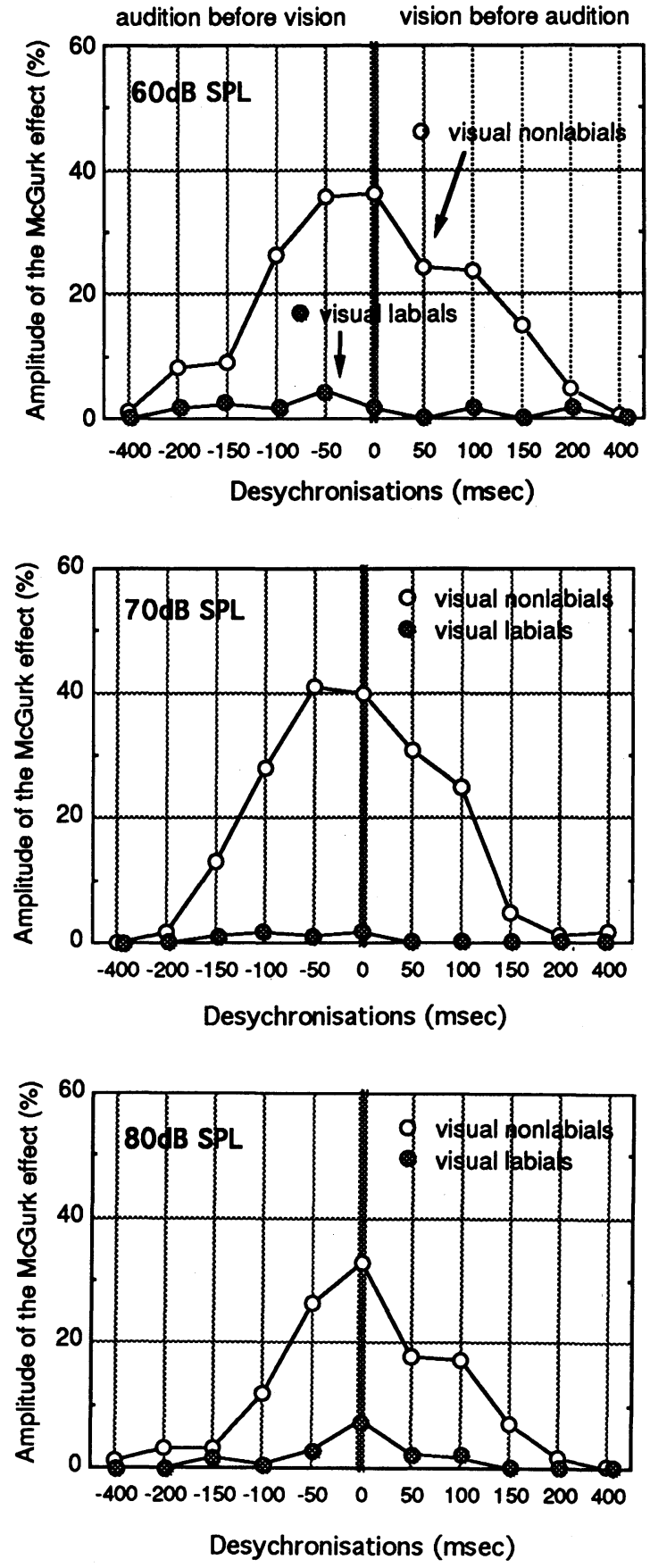

図1 視觉刺激と恥觉刺激の組み合わせ方の䢖い による McGurk効果の生起率 